\title{
THREE SEQUENCES OF SITE-WRITING
}

The article is comprised of three exercises of "site writing" interrupted by theoretical and methodological intermissions. The sequences take the reader to a topographical and exegetical journey into various images, memory traces and narratives that treat reality as raw material for dreaming. Adopting architectural historian Jane Rendell's critical framework of site writing, the article aims at radical spatialization of the sites through which narratives emerge, memories are revisited and possibilities for the future are suggested. Site writing is not writing about spaces, but writing spaces, engaging the materiality of the images and the phenomenological encounters with them through spatiality and positioning of the images. Thus, images become sites through which the narrative unfolds.

The image-sites that form the three key sequences include the juxtaposition of two towns- Kars and Giumry- in Turkey and in Armenia respectively in a way that the images of the townscapes neither comment, nor repeat, but double each other; a journey through Los Angeles' Westin Bonaventure hotel and its relationship to the body and the landscape; and a reading of the latent possibilities of the material in artist Kasper Kovitz's landscape paintings and installations.

SITE-WRITING

IMAGE 


\section{INTRODUCTION}

Several months ago I spent approximately four months trying to renew my passport through the Embassy of Armenia in Beirut. While waiting "before the Law" I thought I developed a profound understanding of the way in which bureaucracy calls for a radically embodied self. While waiting "before the Law" to receive my passport, not getting answers to numerous phone calls, connecting my heartbeat to the dial tone and the anticipation of a voice on the other end of the phone cord, and my voice changing from trembling and pleading to a forceful baritone, I understood that the abstraction and disembodiment of the subject as it gets inscribed in bureaucratic quagmires requires a radical exaggeration of the body's psycho-somatic responses: it calls for a body that experiences pain and pleasure, a pulsating anxiety and jubilant pleasure "before the Law". Thus, the administration of the subject does not take place at the expense of the elimination of the body/self, but precisely through a forceful embodiment.

In Kafka's Parable "Before the Law", Joseph K. spends a lifetime in front of the gate to enter the Law, but his entry is repeatedly prevented by the gatekeeper who has a sharp pointed nose, a fur coat and a thin, black Tartar's beard. As Joseph K. grows old, he shrinks while the gatekeeper grows taller. "Finally his eyesight grows weak, and he does not know whether things are really darker around him or whether his eyes are merely deceiving him. But he recognizes now in the darkness an illumination which breaks inextinguishably out of the gateway to the Law. Now he no longer has much time to live. Before his death he gathers in his head all his experiences of the entire time up into one question which he has not yet put to the gatekeeper. He waves to him, since he can no longer lift up his stiffening body. The gatekeeper has to bend way down to him, for the great difference has changed things considerably to the disadvantage of the man. "What do you still want to know now?" asks the gatekeeper. "You are insatiable." "Everyone strives after the law," says the man, "so how is it that in these many years no one except me has requested entry?" The gatekeeper sees that the man is already dying and, in order to reach his diminishing sense of hearing, he shouts at him, "Here no one else can gain entry, since this entrance was assigned only to you. I'm going now to close it."1

As disempowering as it might be to wait at the gate of the Law, Joseph K.'s anticipation is both a spatial and a temporal deferral of the Law that might open up some political possibilities for the constitution of subjectivity. This temporal "before" maintains the exteriority of the Law and constructs it as an object, against which the time of dwelling posits a livability possible only for 
as long as the appearance of the Law is postponed. ${ }^{2}$ But the Law is topology as well. It is a localizable space that comes only before and after, but never coincides with the subject's presence.

What interests me here, however, is not so much the way in which the abstract Law renders itself powerful because the decaying body of Joseph K, spends a lifetime at its gate, but the way in which the Law renders itself visible - an image that never fully materializes. As his sight diminishes, Law appears to Joseph K. as a form, "an illumination which breaks inextinguishably out of the gateway to the Law" to which he is denied entry. The Law is exteriority that appears as an image, a form, only when one no longer sees. The image through which the Law renders itself visible is in turn governed by a set of conventions. Derrida poses the Law as a convention that constructs the narrative as literature, and the work of interpretation that the reader is engaged with. Is the reader positioned at the gateway of interpretation? Is s/he in the text or outside or it? ${ }^{4}$ I would like to extend the question of interpretation to the reading of images. How do we recognize images? What are the conventions that define something as an image? How do we confront the visual that, according to George DidiHuberman, defies the visible, and yet, is not invisible? ${ }^{5}$ Are we inside images, outside of them, or do we spend a lifetime on their threshold, neither able to leave nor to enter?

\section{SEQUENCE 1: THE PRECARIOUSNESS OF RECOGNITION}

The Empire projects itself as an image first and foremost through architecture. It scars a landscape by building upright standing structures in an attempt to reproduce the provinces in its own image. Architecture is a structure of edification, but edification embedded in the projection of the imperial power marks the other as ultimately not entirely edifiable and as always lacking the perfectly upright posture that would characterize the imperial subject proper. The Empire's image is both a phantasm calling for identification with it, but also an otherness that cannot be completely incorporated in the psychic economy of the imperial non-subject. Architecture simultaneously reflects and performs the ambiguity of phantasmal projection, of recognition and misrecognition, identification and misidentification, with the site from which the power emanates.

The day after the battle is for the administration of things: the Tsar calls for his master planners, imports ornamental motifs that are signifiers of the imperial glory and rushes in cartographers to redraft the existing maps. But 
the architectural mirroring of imperial structures emanating from the center onto the provinces emerges as a slippage, hemorrhage, a bastard child of "the original", and a distorted image. Thus the projection of the imperial power as an image is a flawed one. In the temporality through which the image of power travels from the center to the provinces, what remains of it is merely its shell, an ornament that betrays its original mission. The architecture of the provinces repeats and doubles the imperial glory, but this uncanny doubling produces an abyss, a hollowness that refuses to feed back into the image through which power attempts to render itself visible. If the relationship demanded between the Empire and its subjects is one of love and fidelity, architecture is the law that institutes that bondage.

Two towns are separated by a gorge and a now sealed border. I was born and grew up in one, and only heard stories from my grandfather about the other from where his parents had to escape in the early twentieth century. Kars, a town in Eastern Anatolia was of strategic importance for the Russian Empire in several consecutive wars with the Ottomans: 1828, 18551877 and the World War I. The town became the center of the governorate of Eastern provinces after the Crimean war when the Russian Empire took hold of it in 1878. The specific architecture of the provincial center that developed throughout the late nineteenth and early twentieth centuries was to house the bureaucratic organs of the Empire in order to administer the daily lives of the provincial subjects. This architecture of black and pink porous tuff, whose austere forms were occasionally punctured by delicate weld work or wooden ornamentation, emerged as the replica of nineteenth century Russian imperial architecture. Yet, its raw materiality, its fragile resistance towards delicate handwork because of the precarious porosity of the stone, betrayed its infidelity to the "original". Nineteenth century Imperial architecture of Tsarist Russia in turn had developed as an amalgam of the structure of traditional Russian izbushka (hut) and French Belle Epoque neo-classical elements imported by Peter the Great - that dedicated Europhile who forced his boyars to shave off their "barbarian" beards.

These stone houses often had two stories and a wooden balcony, most of them located on the slope of the hills and extending towards the top. It is these hills that define the topography of the town. Right after securing Kars as its stronghold in Eastern Anatolia in 1878, the Empire brought in architects and urban planners to transform the southern plateau of the city into a new town surrounded by walls with multiple towers. A new Russian church was immediately built, together with single level spacious shops, most of them with 
black tuff and tin roofs, often painted in white or pink. In official Armenian historiography one reads:

The union of Kars with Russia was of a major progressive significance. Similar to Eastern Armenia's earlier unification with Russia, this part of the country also started enjoying progress in economy and culture... Law and order was instituted, and the inhabitants became exposed to incomparably higher and more developed Russian culture. ${ }^{6}$

Giumry, the town I grew up in, is separated from Kars with a gorge, a river and now a blockaded border. From the very first day when the Russian troops marched into the Ararat valley in 1805 , they conquered the town from Persia and used it as a strategic point to occupy the entire valley as well as expand towards the East, the provinces of the Ottoman Empire. The words of a nineteenth century enlightenment writer Khachatur Abovian still have ghostly reverberations: "Blessed be the hour when the Russian foot stepped on the Armenian soil."”

Kars and Giumry shared an often quite mobile population of Armenians, Greeks, Jews and Ezidis, and in many ways, Kars was built as a replica of Giumry. After the Russian conquest, the city was named Alexadrapol after Alexander II. It is here that most of the population of Kars emigrated to between 1915-1920, during the massacres carried out by the Ottomans.

As I grew up in Giumry, I witnessed its many layers (the Russian, the Soviet, the post-Soviet) converging and clashing, as if it was a battle of various pasts enacted upon architecture. However, this symbolic battle was not merely one between various ideologies of the past and ideals for the future. A natural

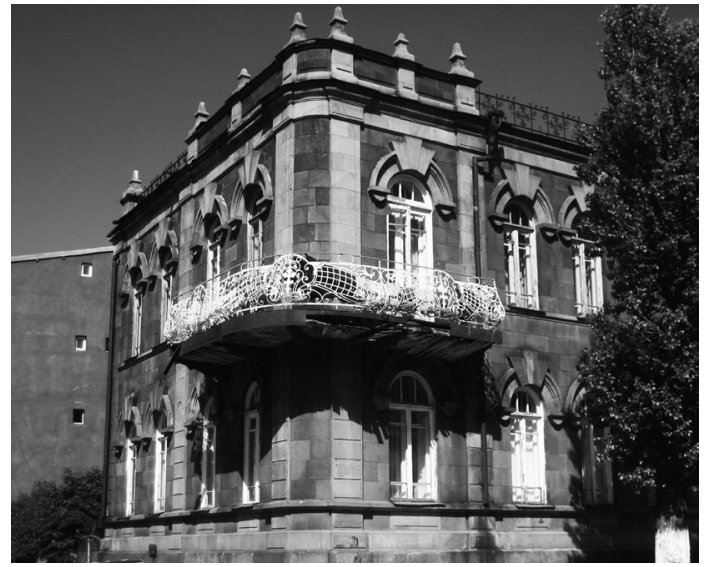

Image 1. Kars, Turkey. Photograph by Angela Harutyunyan.

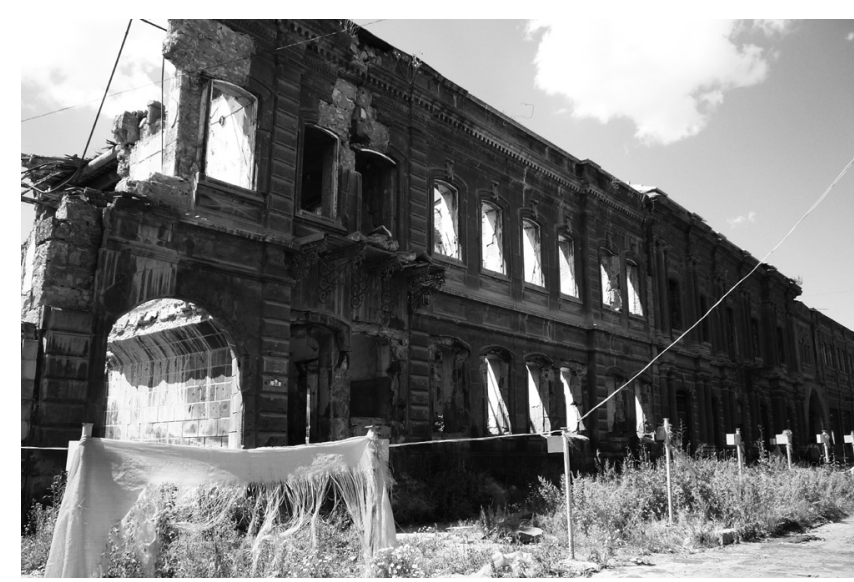

Image 2. Giumry, Armenia. Photograph by Aras Ozgun, 2009. 
disaster in 1988 came to the aid in this symbolic battle by erasing much of the Soviet landscape and exposing the nineteenth century Tsarist townscape in its nakedness. But I never suspected that Giumry had its uncanny double until I arrived to Kars in 2006. And it was not the childhood stories of my grandfather than I had already filtered through a critical distance and disidentification, but the very materiality of the city that arrested me, before I could even enter into its semiotic structure. The familiarity of the place was not based on associations triggered through the empirically constructed space that go along the lines of "this reminds me of...", but the horror of the double (Image 1 and 2). In Freud's sense, the uncanny is an aesthetic notion, a notion that pertains to the "quality of feelings" triggered by the quality of things. He says that "The 'uncanny' is that class of the terrifying which leads back to something long known to us, once very familiar" (heimlich). But the familiar is stretched to such an extent that it ambiguously reaches its opposite - the unheimlich in which "the prefix -un is the token of repression." "

The doubling of the two towns not only in the sense of architectural sameness, but also the exactitude of their afterlife creates double ghosts: the ghost of the empirical repetition and the ghostly repetition of this ghost in the afterlives of the two towns. But the uncanny is also profoundly connected to narcissism in that the doubling springs from self-love, from the desire to project oneself to eternity (afterlife, soul, ghost, etc.). The power of the Empire renders itself as a phantasmagoric image through architectural doubling, a narcissus absorbed by its own image in a perpetual present that demands love and fidelity from its subjugated others. But the ambiguity with doubles, as Freud has been telling us, is that they turn from reassurances of eternity (ghosts, souls) to the ghastly harbingers of death.

\section{Intermission}

In "You Tell Me" architectural historian Jane Rendell offers "site-writing", a spatial narrative constructed through topographical fiction and existing visual codes within a space informed by subjective experiences. ${ }^{9}$ But the space itself is never a given but comes into being through the embodied experience. Site-writing is not writing about spaces but writing spaces, engaging with images through their own intrinsic materiality and spatial positioning. It is not an ekphrasis, but an exegesis that opens the images to the possibility of seeing and un-knowing and knowing and un-seeing. Exegesis does not form a discourse that invents the object in its own image, but if need be, resigns before the image that exceeds both the interpretation and its own materiality. The topography of the image is not the topography of our empirical space. 
It is dreamlike topography in which various spatialities and temporalities converge, overlap and clash. It is a dreamwork in a Freudian sense, understood as a condensed space/time in which "sheds [are] put together". The space of the image and the space of the dreamwork collide in yet another sense: they both offer visual intensity that is comprised of contradictory, clashing and overlapping composites, and yet take the referent as a material for the dream/ image work.

\section{SEQUENCE 2: THE SPACE UNDONE}

Power demands its material support. The reflective surfaces of skyscrapers conceal their structure and materiality with the promise of infinite virtualization. Their substance appears as nothing but their own appearance, the surface that reflects the surrounding with the effect of infinite regression and mirroring. As a hall of mirrors it projects a sublime presence of effortlessness. The skyscraper is a myth of a historic necessity and a natural order of things, two sides of the same coin. The postmodern skyscraper projects itself onto other surfaces while being constituted by these surfaces as a holograph, a pure transparency of instant materialization and de-materialization. The skyscraper is connected with other structures through bridges and underpasses, it is a pure network that epitomizes the networked structure of the only pertinent ideology of our times: that of the global financial system.

I arrive to Westin Bonaventure hotel downtown Los Angeles, and enter the labyrinthine maze of the lobby through a half-concealed and lateral entrance on Figueroa street that provides a closure to the hotel rather than an opening. The lobby seems to provide the only foundation upon which the four disjointed glass towers hover, suspended between the ground and the sky (Image 3). The
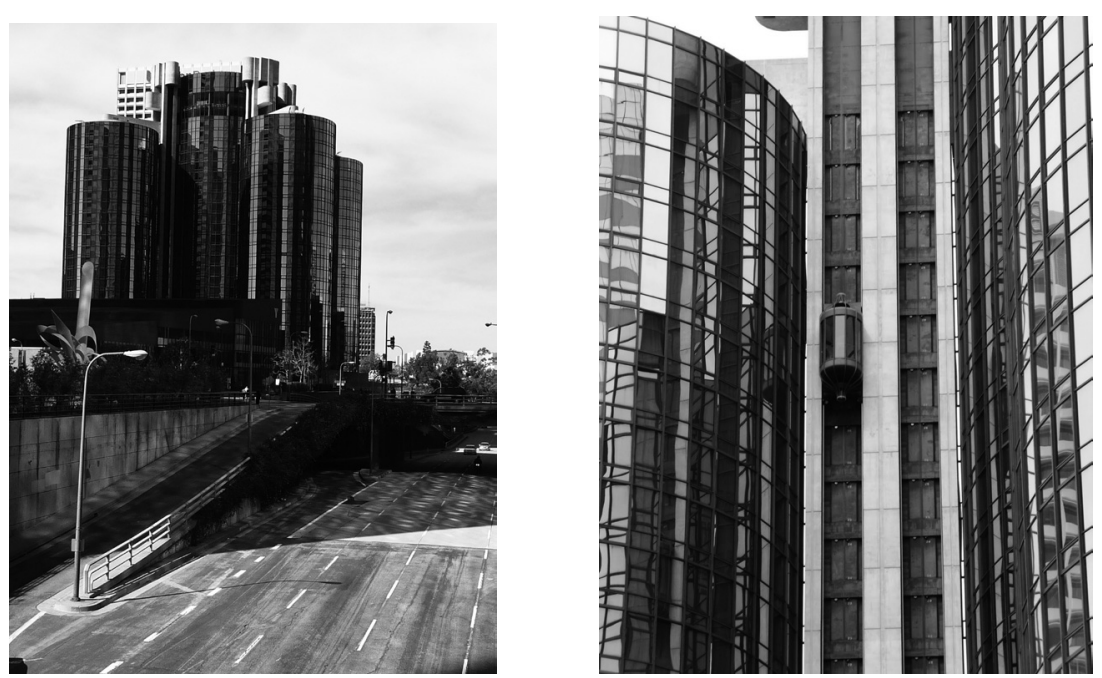

Image 3-4. Westin Bonaventure Hotel, Los Angeles. Photograph by Angela Harutyunyan, 2012. 
lobby is also the only walkable space in the entire structure where otherwise disjointed parts are connected through dozens of elevators and escalators. One can go up in an elevator in each of the four disconnected towers that spring up from the atrium. In an attempt to restore the coordinates of bodily orientation, each tower has its own coded color to guide the visitor to hotel rooms. Each tower has one and a single referent: Los Angeles itself with its sprawling network structure (Image 4).

Each and every time I am compelled to document my journey to the twenty forth floor and back to the ground floor lobby. Each journey is different since the elevator will stop on different floors to carry other guests, thus the rhythm of the video will change upon these stoppages. In addition, there are at least twenty possibilities to make different videos from various vantage points and angles. The journey consists of two parts: firstly the elevator shoots through the ceiling of the enclosed atrium in what seems to be a much faster pace because of the closeness of the walls and other structural elements to the glass shell of the elevator. The pace of the journey seems slower and the position of the onlooker becomes panoptical once one leaves the "Lower Circle" (in Dante's sense) of the material structure and appears suspended between the ground and the sky, surrounded by the sprawling city. The downward journey is more dramatic, and reverses the dialectic between openness and closure: the journey culminating in the "inferno" of the hotel lobby with the elevator literally splashing into the artificial lake.

I am constantly in the image, the image that projects its glittery surface as a phantasmagoric space of inclusion, yet excludes those who inhabit the other side of downtown Los Angeles - the homeless, the drug addicts, alcoholics, former inmates, drag queens, who dwell under the bridges and in the riverbed. Yet, while in the image, I want to externalize it, to split myself from it and to regain my body that has been violently turned into a reflection. It has been deprived of its capacity to move freely and is being carried through automated devices such as elevators and escalators. Or rather, I want to eject myself out of the image by putting the burden of seeing on the camera/eye.

While I am between the visual trap I submitted myself to and the critical distance I force myself to inhabit, I recall Fredric Jameson's paragraphs on Westin Bonaventure. For, Jameson locates a radical rupture with modernist architecture that inhabits the surrounding cityscape with its utopian promise as a disjunctive proposition for a different aesthetics of living than the surrounding environment can accommodate in the present. Instead, John Portman's 1977 building "seeks to speak [the] very language [of its surrounding environment], 
its lexicon and syntax", and acts as a "populist insertion into the city fabric... As a total space, it corresponds to a new collective practice ... something like the practice of a new and historically original kind of hyper-crowd." 10

The escalators and elevators that occupy a special place in Jameson's description as well as in Portman's architecture, epitomize what Jameson calls "a dialectical heightening" of the process of narrativisation of architecture that the visitors have to fulfill. He continues: "It seems to me that not only do the escalators and elevators here henceforth replace movement, but also and above all designate themselves as new reflexive signs and emblems of movement proper... Here the narrative stroll has been underscored, symbolized, reified and replaced by a transportation machine which becomes the allegorical signifier of that older promenade we are no longer allowed to conduct on our own. This is a dialectical intensification of the autoreferentiality of all modern culture, which tends to turn upon itself and designate its own cultural production as its content." 11

Jameson's principle point is that in postmodern architecture, as it is epitomized in Portman's iconic building, the body is forced into heightened mobility alongside with the infinite mobility of other signs and semiotic systems that define the space, but the trajectories and pace of this movement are always already prescribed by automated devices that carry the body. It is no longer the body that organizes its own perceptual space and maps itself onto it. It is now the space that carries the body through and within it and "maps cognitively [the body's] position in a mappable external world." ${ }^{12}$ The implications of this disjoining are much more profound than simply the relationship between the body and the built environment. What is at stake is a production of the subjectivity within this newly networked hyperspace and which reflects "the incapacity of our minds, at least at present, to map the great global, multinational and decentered communicational network in which we find ourselves caught as individual subjects." 13

\section{Intermission}

The topographical approach to images as material sites demands that the sitewriter investigates the position s/he occupies in relation to images, the locations these images are inscribed in and refer to and the spatial issues they raise, not only conceptually and ideologically, but also materially and emotionally, in order to write texts that locate the spatial themes triggered by an encounter with images in written form. ${ }^{14}$ Not only the beholder, the writer positions herself and her body in relation to images, but the way images are encountered 
becomes significant. It is almost like the objective chance of the surrealists: a détournement of discovering the marvelous: a predetermined contingency that cannot happen otherwise but at the same does not have to happen. According to Jane Rendell, site-writing or topography is a constant move back and forth, between the inside and the outside - the images with which the writer engages invite her inside but also define her as always external. ${ }^{15}$

Writing images as sites is to enter into a labyrinthine maze where the narratives are placed inside one another, and where one is to get lost. Site-writing defies the art historical search for the truth of the referent and resemblance, and bypasses the architectural and temporal coordinates of the mausoleum (museum) in which images are fixed and the space is pre-configured. The domain of the images is the rein of the Minotaur that traps the one attempting to enter the maze of interlacing spatialities. Here I am not offering a reading of images that provides a rational explanation of their iconography, catalogues stylistic references or attempts to locate factual truths, but I am proposing to spend a lifetime before artistic images, the way in which Joseph K. spent a lifetime before the Law. But instead of a lifetime spent, I am proposing an exegesis that opens up the images to a multiplicity of meanings but also, towards the impossibility of knowing that defies the myth of their omni-translatability. ${ }^{16}$

\section{SEQUENCE 3: EFFACING TRACES OF LABOR}

Narrative painting has been one of the greatest causalities of the twentieth century. First it was overcome by modernism as a vestige of the Ancien Regime for the sake of painting's triumphant reduction to the physicality of the medium as the culmination of its teleological evolvement. Then it was deconstructed by postmodernism because of its ideological connotations, and has rarely marked a comeback under post-medium conditions.

In her recent book Under Blue Cup art historian Rosalind Krauss attempts to salvage the medium as technical support by those practitioners who re-invent it in the post-medium oblivion brought about by installation art and the institutional critique of the white cube. Several years ago Krauss underwent extensive mnemonic therapy to re-learn to connect signs with signifiers after aneurysm - a condition when "an exploded artery launches a cataract into the brain disconnecting synapsis and washing the neurons away." ${ }^{17}$ Taking this recovery as a metaphor, she argues for the memory of the medium is a set of rules, a unified discourse for a given period that is both recalled and reinvented. Unlike the Greenbergian formalist reductionism of the medium to the physicality of its 
support, Krauss asks the question of the "who you are" of the medium in terms of technical support. "I am substituting 'technical support' for the traditional idea of the medium... technical supports are generally borrowed from mass cultural forms like animated films, automobiles, investigative journalism, or movies - hence, 'technical' replace the 'artisanal' materials of the guilds." 18 Krauss" "knights of the medium" include Ed Rusha whose technical supports are automobiles, William Kentrige whose "elaboration of animation by means of painstaking erasure" recalls the memory of the medium, and Haroun Farocki who "foregrounds the video's editing bench", amongst others. ${ }^{19}$ Ultimately, Krauss strives to salvage the visual from its obliteration by those practices that harness a fundamental distrust towards the ontology of the medium. If the technical support is the "discursive unity" of a given epoch, the way in which the checkered board served as a support (in the sense of providing a set of rules) for the Renaissance linear perspective, can landscape become such a support for narrative painting in the post-medium condition? Can the narrative be told through the very materials that it inhabits?

Artist Kasper Kovitz' works consistently weave a single narrative. However, this is a narrative that has a multiplicity of paths and a variety of stories depending on which path the beholder takes. It is as in a fairy tale where the protagonist faces several paths and has to choose only one based on pure chance or intuition. Here a rational choice is of no help, but the paths chosen are those that lead to a manifest destiny. Kovitz's landscape paintings and three-dimensional works that support these narratives, however, are not about a story, but they are a story. One could call them "surviving images" that carry the memory of the medium, and yet re-invent it with their latency and tenacity. The various narrative paths that one takes in these landscapes are trails in dense forests, footprints on ice lakes, tracks in abandoned gardens and roads

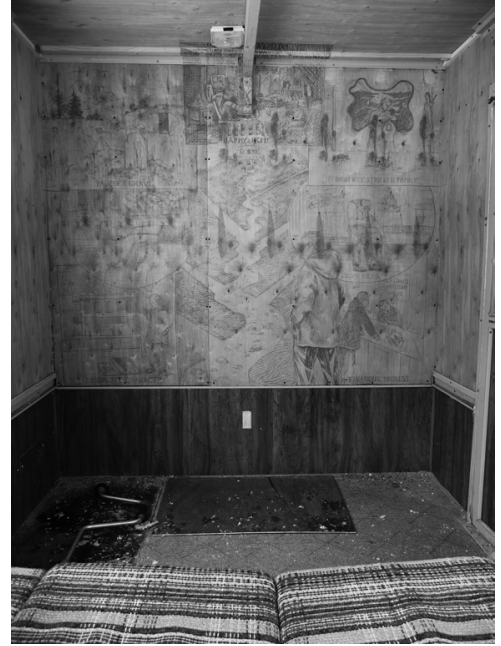

Image 5. Kasper Kovitz, Ice House. Still from the video. Nova Scotia, Canada, 2010. Courtesy of the Artist

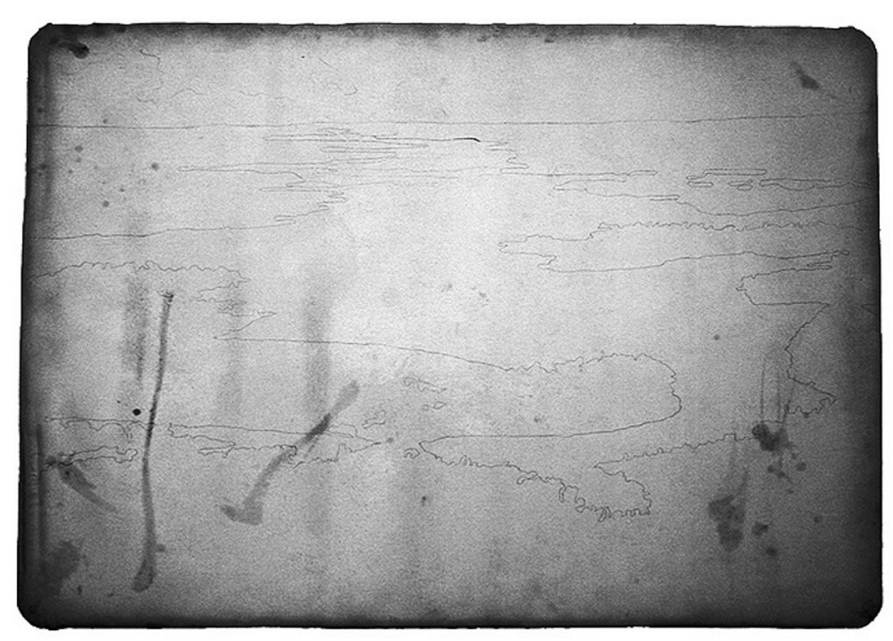

Image 6. Kasper Kovitz, Common Prayers - eucharist [Buzzard Roost; Lake Greenwood SC], pencil on discarded under-bed, 2000. Courtesy of the Artist. 
in villages trodden by those who pursue manifest destiny, or no one at all. In Icehouse of 2010, the landscape literally becomes a support structure that sustains the pencil drawings graphed on the wall during Kovitz's two-week stay in a trailer on an icy lake in Canada, but also literally bears the artist's life supports - the ice house and his body (Image 5). Here the relationship between Kovitz and the landscape is one of trust. But the danger of trust and the danger of medium specificity are, as Stanley Cavell tells us, inherent in the experience of art and the experience of inhabiting the present. ${ }^{20}$

Kovitz's landscapes of memory are punctured or zipped through by an intrinsic element that is ejected out of the landscape, yet belongs to it. The tension between a seeming harmony and its disturbance, the serenity of landscapes and the traces of violence and history "contaminating" them is articulated at the level of the materials and forms. These landscapes have been violated doubly: being turned into a flat image through mechanical reproduction (he always takes a postcard or a photograph as a starting point), they are consigned to the nomadic life of exchangeable signs, but they also bear traces of the desire for conquest. Nevertheless, there is no original innocence that they can regain.

The series Common Prayers is based on an old postcard of Buzzard Roost; Lake Greenwood in South Carolina. What comes first is Common PrayersEucharist of 2001 - a pencil drawing on a dirty under-bed (Image 6). Here the fragile outlines of the landscape graphed with pencil on a discarded under-bed are punctured by stains embedded within the material. These outlines carry the memory of the stain, yet they reinvent the medium through their accidental character. The artist explains that he thought of the work as the "tabula rasa" that "land-takers" (in this case Puritans) hoped to find. "Eucharist" is referred to in its ancient Greek meaning of "Thanks Giving", but also as a religious

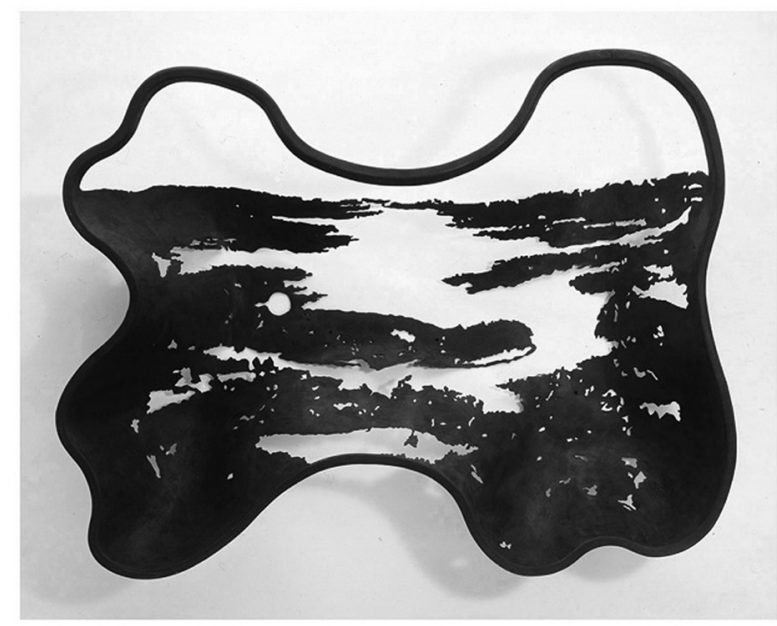

Image 7. Kasper Kovitz, Common Prayers - all the friends I ever had are gone [Buzzard Roost; Lake Greenwood SC], cutout pre-formed polyethylene pond, 2001. Courtesy of the Artist. 
term for the most significant magical transformation around which the rite of a mass is centered. ${ }^{21}$ But this tabula rasa revokes the abject as it has been already stained by those sleeping on the under-bed. This is followed by Common Prayers: Recreation, which is a failed attempt at reconstructing the landscape in its three-dimensionality. The final piece in the series Common Prayers - All the Friends I Ever Had Are Gone (Image 7) transfers the outlines of the landscape on cutout-preformed polyethylene that forms a pond. The matter contained within the curvilinear frame becomes a negative image of the photograph of the original landscape. The pond is punctured by a hole that serves as the punctum of the image, belonging to it, yet creating a caesura within the still recognizable form of the landscape.

As yet another attempt at recreating the landscape in its three dimensions, the work moves further away from the found post-card. The landscape is rather no longer represented, but becomes a technical support that precariously holds the forms together. Kovitz claims that there is an obviousness that signifies a state for him, where the closer one gets to recreation the further one gets away from it at the same time. He quotes the poet Philip Larkin who, when answering the question "What have you learned from other poets?" in an interview for the 1982 Paris Review, replies: "NOT TO BE AFRAID OF THE OBVIOUS." Kovitz further states: "Merriam Webster has "obvious" as: 1) archaic: being in the way or in front, and only 2) easily discovered, seen, or understood. I kept and keep revisiting this poetic scare in my work and it holds a fascination for me, but also comes with a sense of dread, of utter departure, of reaching an end and feeling the cold of utter loneliness."22

In Neversink (2011) the landscape of Neversink Dam in New York goes through a multiplicity of dimensional transformations in such a way that it

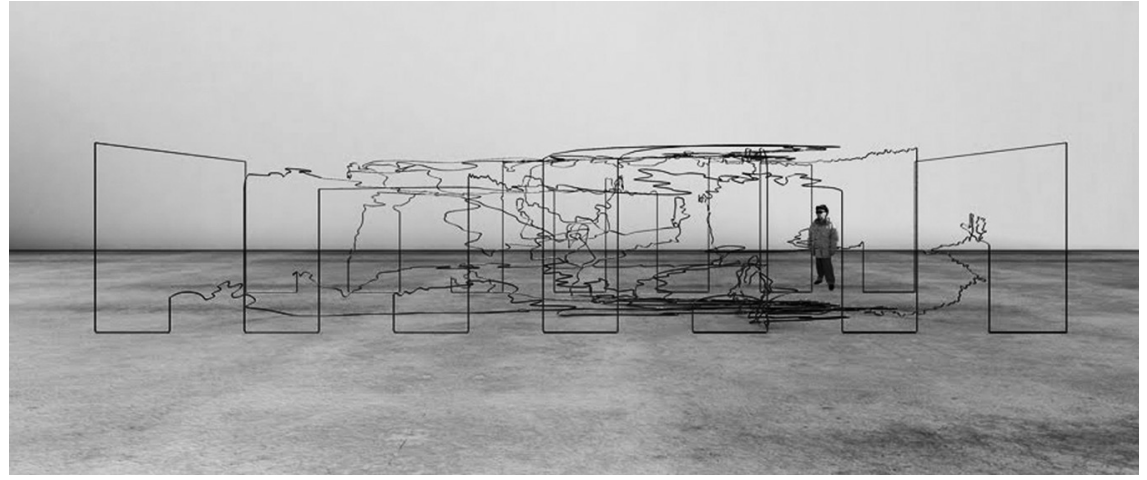

Image 8. Kasper Kovitz, Neversink, 1/2" cold - rolled steel pipe, Length: 42' 9", $13 \mathrm{~m} 29 \mathrm{~cm}$, Width: 13' 4", 4m 7cm Hight: 8" 4", 2m 54cm, 2011. Courtesy of the Artist.

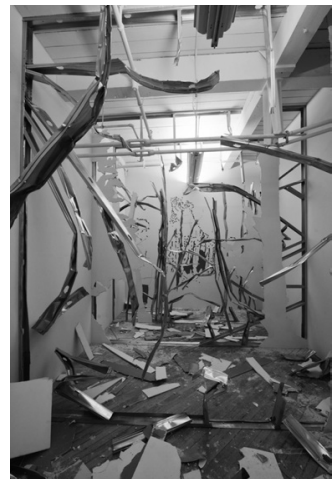

Image 9. Kasper Kovitz, Rate Your Progress, Schoharie, New York, 2009. Courtesy of the Artist. 
no longer reproduces the Cartesian coordinates even in its three-dimensional spatialization. Kovitz chooses a postcard of the Dam (the space rendered as a reproducible two-dimensional image), then transfers the outlines of the landscape back onto the third dimension. However, this double translation betrays the actual landscape as a referent since the work that emerges is a maze of discreet lines, a result of "tracing" (both in a sense of technicality and as a trace) that envelopes the viewer's body (Image 8). The doubly transformed three-dimensionality appears as strange, vertiginous and dazzling since it both promises reconstitution of the familiar spatial coordinates but then withdraws that promise. The rigid frame supposed to provide a support structure, a grounding to regain the Cartesian coordinates, clashes with the intensity of the moving lines, the lines that run through the unyielding outlines as its electrified nervous system.

Rate Your Progress (2009) is based on a reproduced image of a jungle in Vietnam cleared due to a fallen bomb (Image 9). The forest that would otherwise see no light becomes an index in the three-dimensional rendering of the image where the referent collapses. What is left is the experience of the place; an experience that has not been lived. The six constructed walls cannot contain matter violently puncturing the walls and aggressively threatening the viewer's entry.

Kovitz uses post-painterly materials to make paintings: fox's urine, bear scat, pine sap and coffee, amongst others. But these materials carry the traces of narratives in them, or rather; they are what I would call paradox-materials since they point to a referent that has escaped (Image 10). They function as indexes pointing to a story that has disappeared, as if from a crime scene. Here the story is not to be found behind the painting, but in the opacity of materials,

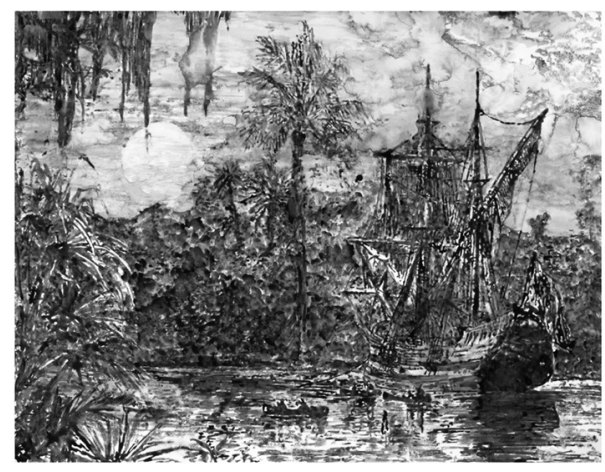

Image 10. Kasper Kovitz, Parime [Ponce de Leon], oxblood on paper $295 / 8^{\prime \prime}$ x 22 11/16", 75.2 x 57.6cm, 2010 . Courtesy of the Artist.

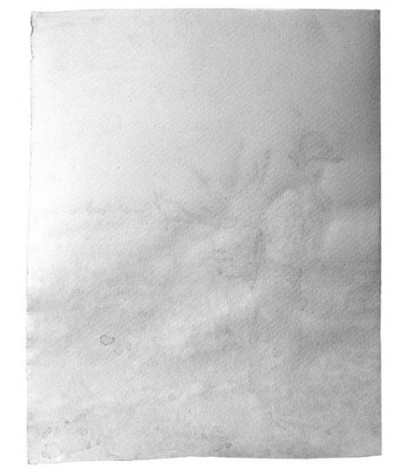

Image 11. Kasper Kovitz, No title; coyote urine; 2008; 9 1/2" x12 $3 / 8,2009$. Courtesy of the Artist. 
as visually transparent as these might seem. The promise of the transparency of the sign as providing a key to decoding the painting runs against the opaque materiality of the image. But often, the paradox-materiality of the landscape (as a technical support) through its thickness, but also elusiveness conceals the image from immediate visibility. Thus, the beholder is to pull the image out of its latency so that it enters the domain of the visual. This visuality in turn is haptic in that the viewer's body/brain is activated in the process of the materialization of the image by pulling it out of its latency (Image 11). The landscape as technical support holds the precariousness of the image that is yet to materialize but at the same time is on the verge of collapse. This requires that the viewer gets closer to the painting to penetrate its materiality. The viewer is compelled to visually crop and cut it, to exercise violence over it, the violence of the gaze that has a capacity to frame that which has been already pre-framed. Yet, the intrusive order of the gaze surgically intervenes into the very matter of what promises a coherent and instantaneous visual consumption. The viewing subject, in turn, is split between the desire to comprehend the whole and the need to break it apart. This is the long duree of the image, its temporality exceeding the physicality of its medium. 1992), 183-220. (The Pennsylvania State University Press, 2005),15. Mourning of the Patriot), 1841, in Armenian. Available online in http://hy.wikisource.org/ wiki/ 
Ibid., 52.

Ibid., 44.

Ibid.,

Jane Rendell, "You Tell Me: A Topography”, p. 83.

Ibid.

George Didi-Huberman, Confronting Images. Questioning the End of a Certain History of Art, p. 16.

Rosalind Krauss, Under Blue Cup (The MIT Press, Cambridge, Massachusetts, 2011), 1.

Ibid., 19.

Ibid., 33.

Ibid., 69.

From a private unpublished correspondence with the artist. June, 2012.

Ibid.

Abovyan, Khachatur. Verq Hayastani, voghb hayrenaseri (The Wound of Armenia, the Mourning of the Patriot), 1841, in Armenian. Available online in http://hy.wikisource.org/ wiki/

Derrida, Jacques. "Before the Law." Acts of Literature. ed. Derek Attridge. London: Routledge, 1992.

Didi-Huberman, George. Confronting Images. Questioning the End of a Certain History of Art. The Pennsylvania State University Press, 2005.

Freud, Sigmund. "The Uncanny", Collected Papers, 4:399/Studienausgabe, 1959.

Jameson, Fredric. Post Modernism, Or, The Cultural Logic of Late Capitalism. Duke University Press, 1991.

Kafka, Franz. The Collected Stories. New York: Shocken, 1971.

Krauss, Rosalind. Under Blue Cup. The MIT Press, Cambridge, Massachusetts, 2011.

Rendell, Jane. "You Tell Me: A Topography", in Public Spheres After Socialism. ed. Harutyunyan A., Public Spheres After Socialism. Miles M, Horschelmann K., Intellect Press, 2008.

Zhamkochyan H.G. Hay Joghovrdi Patmutyun (History of the Armenian People). National Academy of Sciences of Armenia, 2006 (in Armenian). 


\section{PROSTORI RAMIMOILAŽENJA}

\section{Barbara Steiner}

Ovaj tekst postavlja pitanje kako neslaganje može prostorno da se organizuje. Premda, uzimajući nedavne razvoje u umetnosti, arhitekturi i urbanom planiranju u razmatranje, $u$ fokusu su dva projekta umetnice i arhitekte Apolonije Šuštrešič: kafe KAFIČ, koji je naručila Galerie für Zeitgenössische Kunst Leipzig i (Community Pavillion) Paviljon zajednice u Hustadtu, koji je naručila opština Bochum. Prateći ova dva primera ovaj tekst razmatra mogućnosti kako da se društveni antagonizam preobrazi u agonizam time kreirajući živahnu javnu sferu koja dozvoljava izražavanje takmičarskih pojmova, mišljenja i prilaza.

KLJUČNE REČI: NESLAGANJE, KONFLIKT, RAZILAŽENJE, JAVNI PROTSOR, ANTAGONIZAM, AGONIZAM

POJAM I ZNAČENJE MEĐUDISCIPLINARNOSTI

U PROUČAVANJU UMETNOSTI I MEDIJUMA

\section{Nikola Dedić}

Ovaj tekst pokušava da označi razliku između tradicionalnih, modernih monodisciplinarnih i savremenih međudisciplinarnih prilaza u okviru analize prijema medijskih i umetničkih sadržaja. Monodisciplinarni prilazi su povezani sa klasičnom osnovom humanističkih i društvenih nauka koje su povezane sa defincijom kulture zasnovanom na suprotnosti masovne i elitne kulture (umetnosti). Avant-gardni i lingvistički preokret u okvru društvenih nauka šezdesetih je realizovao ponovno prosuđivanje vrednosti pojma kulture - kultura se više ne posmatra kao zbir elitnih proizvoda ljudskog duha već pre kao proizvodnja kulturnih značenja, tj. kao diskurs. Ovaj preokret je omogućio međudsiplinarni preokret u okviru nauka kao što je estetika i istorija umetnosti $\mathrm{i}$ isto tako omogućio pojavu savremene, međudisciplinarne teorije medija.

KLJUČNE REČI: MONODSCIPLINARNOST, MEĐUDISCIPLINARNOST, MODERNIZAM, POSTMODERNIZAM, TEORIJA UMETNOSTI, ESTETIKA, ISTORIJA UMETNOSTI, AVANT-GARDA, TERIJA MEDIJA, PROUČAVANJA KULTURE

TRI SEKVENCE PISANJA-LOKACIJE

\section{Angela Harutyunyan}

Ovaj članak obuhvata tri vežbe/zadatka „pisanja lokacije“ prekinuta teoretskim i metodološkim pauzama. Ove sekvence odvode čitaoca u topografska i eksegetička putovanja u razne slike, tragove memorije i priče koji tretiraju 
stvarnost kao sirovinu za sanjarenje. Usvajajući kritički okvir pisanja lokacije istoričara arhitekture Džejn Rendel ovaj članak ima za cilj radikalno pravljenje prostornosti tih lokacija kroz koje se priče pojavljuju, uspomene se preispituju i mogućnosti za budućnosti predlažu. Pisanje lokacije nije pisanje o prostorima, već pisanje prostora, koje angažuje materijalnost slika i fenomenološke susrete sa njima preko prostornosti i pozicioniranja slika. Stoga, slike postaju lokacije kroz koje se priča odvija.

Slike-lokacije koje obrazuju ove tri ključne sekvence obuhvataju postavljanje dva grada jednog do drugog - Kars i Guimry - u Turskoj i Jermeniji tim redom na takav način da se slike panorame gradova niti komentarišu, niti ponavljaju, već se uzajamno dupliraju; putovanje kroz Westin Bonaventure hotel u Los Anđelesu i njegov odnos prema telu u pejsažu; i čitanje latentnih mogućnosti materijala u slikama pejsaža i instalacijama umetnika Kasper Kovica.

KLJUČNE REČI: PISANJE-LOKACIJE, SLIKA, ZAKON, TEHNIČKA PODRŠKA, PEJSAŽ, ARHITEKTURA 